\title{
DEVELOPMENT AND VALIDATION OF AN ANALYTICAL METHOD FOR THE DETERMINATION OF RELATED SUBSTANCES IN BISOPROLOL FUMARATE IN DOSAGE FORMS BY HPLC-UV-DAD
}

\author{
Elena Lazarevska Todevska ${ }^{1,2}$, Marjan Piponski ${ }^{1}$, Marina Stefova ${ }^{2}$ \\ ${ }^{1}$ Replek Farm Ltd, Quality Control Department, Skopje, RN Macedonia \\ ${ }^{2}$ Institute of Chemistry, Faculty of Natural Sciences and Mathematics, \\ Ss. Cyril and Methodius University, Skopje, RN Macedonia \\ elenalazarevska@yahoo.com
}

\begin{abstract}
The aim of this work was the development of an efficient analytical method for the determination of bisoprolol and related substances in the finished drug product using HPLC/DAD. Different bonded phases (alkyl and phenyl) with variable pore sizes and column dimensions, temperatures, and mobile phases with variable $\mathrm{pH}$ and additives were tested. Experiments that included using Hypersil 3 BDS C18 $100 \times 4 \mathrm{~mm}, 3 \mu \mathrm{m}$; Zorbax SB C18 $150 \times 4.6 \mathrm{~mm}, 3.5 \mu \mathrm{m}$; Acquity UPLC BEH C18 $50 \times 2.1 \mathrm{~mm}, 1.7$ $\mu \mathrm{m}$; and Xterra MS C18 $100 \times 4.6 \mathrm{~mm}, 3.5 \mu \mathrm{m}$ gave the best results when considering the separation and resolution of the tested analytes within a reasonable run time. The method using Xterra MS C18 $100 \times$ $4.6 \mathrm{~mm}, 3.5 \mu \mathrm{m}$ was validated as the most suitable when taking into account the mobile phase preparation and versatility, analysis time, and equipment maintenance.

Validation parameters (linearity, accuracy, precision, selectivity) confirmed the method as suitable for its intended use.
\end{abstract}

Key words: bisoprolol; related substances; forced degradation studies

\section{РАЗВОЈ И ВАЛИДАЦИЈА НА АНАЛИТИЧКИ МЕТОД ЗА ОПРЕДЕЛУВАЊЕ СРОДНИ ОНЕЧИСТУВАҢА НА БИСОПРОЛОЛ ФУМАРАТ ВО ДОЗИРАНИ ФОРМИ СО ПРИМЕНА НА HРLC-UV-DAD}

Целта на ова истражување беше развој на ефикасен аналитички метод за определување на бисопролол и сродни онечистувања во дозирани форми со примена на HPLC/DAD. Тестирани се различни типови стационарни фази (алкил и фенил) со варијабилна големина на порите и димензии на колоната, температура, како и мобилни фази со различна вредност на $\mathrm{pH}$ и адитиви. Експеримените кои вклучуваат примена на Hypersil 3 BDS C18 $100 \times 4$ mm, $3 \mu \mathrm{m}$; Zorbax SB C18 $150 \times 4.6 \mathrm{~mm}, 3.5 \mu \mathrm{m}$; Acquity UPLC BEH C18 $50 \times 2.1 \mathrm{~mm}, 1.7 \mu \mathrm{m}$; и Xterra MS C18 $100 \times 4.6 \mathrm{~mm}$, $3.5 \mu \mathrm{m}$ дадоа најдобри резултати земајќ ја предвид сепарацијата и резолуцијата на испитуваните аналити во разумно време на анализа. Методот со примена на Xterra MS C18 $100 \times 4.6 \mathrm{~mm}, 3.5 \mu \mathrm{m}$ беше предмет на валидација, како најсоодветен од аспект на повторливост при подготовката на мобилната фаза, времето на анализа и одржување на опремата.

Параметрите кои беа предмет на валидација (линеарност, точност, прецизност, селективност) потврдуваат дека аналитичкиот метод е соодветен за неговата намена.

Клучни зборови: Бисопролол, сродни онечистувања, студии на форсирана деградација. 


\section{INTRODUCTION}

Bisoprolol is classified as a beta-1-adrenergic cardioselective blocking agent along with other beta-blocking adrenergic agents, such as atenolol, acebutolol, metorpolol, and nebivolol. Its mechanism of action is in decreasing the myocardial contractile force and thus lowering the blood pressure. This pharmacological group is widely used in the treatment of hypertension and angina pectoris and is a subject of great interest in the pharmaceutical industry $[1,2]$.

Literature search showed that several methods are available for the determination of related substances of bisoprolol fumarate. Some of them are transfers of the pharmacopoeial method described in the British Pharmacopoeia (BP) for bisoprolol fumarate as an active substance [3,4], but there are also other methods such as optimized hydrophilic interaction liquid chromatography (HILIC) methods for the analysis of bisoprolol and its related substances [5], for determination of the degradation products of bisoprolol fumarate under different stress conditions [6], for the structural characterization of related substances of bisoprolol fumarate [7], as well as methods using sub-2- $\mu \mathrm{m}$ adsorbents that bring a significant reduction in the analysis run time and solvent consumption [1]. Additionally, methods have been developed for the determination of the content of bisoprolol fumarate as well as for the simultaneous determination of the content of bisoprolol fumarate combined with hydrochlorothiazide and amlodipine besylate [89]. A fully validated HILIC method has been proposed for the determination of bisoprolol fumarate in combination with amlodipine besylate $[10,11]$.

The current status in the area of research related to quality control revealed that there are several available methods for the determination of the content of bisoprolol fumarate as an individual active substance or in combination with antihypertensive or diuretic active pharmaceutical substances [1-4, 8-11], but there are only a few papers that have reported analytical methods for the determination of bisoprolol and its potential related substances [5-7]. The analytical method for the determination of related substances transferred from the British Pharmacopoeia is usually employed because it reduces the need for validation of the method, but its drawback is the long run time, which is an important issue when it comes to routine analysis in quality control laboratories, especially in early phases of product development and stability testing.
The main objective of this study was to develop and optimize an analytical method for the determination of related substances of bisoprolol fumarate in the finished drug product that will be time efficient, robust, and applicable to everyday quality control with proven performance and the possibility of separating the critical pairs of peaks. Critical pairs refers to the separation of peaks due to bisoprolol impurity A and fumaric acid, as critical pair 1 , and the separation of peaks originating from bisoprolol and bisoprolol impurity G, as critical pair 2. Along with the satisfactory separation of the critical pairs, it is also very important to obtain a good peak shape and a reasonable retention time of bisoprolol impurity E. Development of a new analytical method for the determination of related substances of bisoprolol fumarate is even more challenging because the number of related substances included in the monograph for bisoprolol fumarate in the European Pharmacopoeia (EP) has reached 15 structural moieties that have been elucidated so far.

Laboratories for quality control in the pharmaceutical industry require methods for everyday practice that need to be rapid, cost-effective, and valid. For this reason, a very important objective was to test the applicability of various stationary phases and columns that are readily available, not very expensive, and can be used with versatile mobile phases in order to have a high-throughput analytical method that provides fast screening results for the overall quality of the product.

\section{EXPERIMENTAL}

\subsection{Chemicals and reagents}

Acetonitrile, phosphoric acid, potassium dihydrogenphosphate, 1-hexansulphonic acid sodium salt, 1-heptansulfonic acid sodium salt, and hydrogen peroxide solution $30 \%$ were purchased from Carlo Erba. Potassium hexafluorophosphate, perchloric acid $70 \%$, and propylamine $98 \%$ were purchased from Sigma Aldrich. Hydrochloric acid $37 \%$ was purchased from Merck, and sodium hydroxide was purchased from Riedel-de Haën.

Bisoprolol for system suitability EPCRS (European Pharmacopoeia Chemical reference standard) and bisoprolol for peak identification EPCRS valid batches were both supplied by the European Directorate for the Quality of Medicines (EDQM). Bisoprolol fumarate working standard (WS) used for quantification was the working standard that was standardized versus the valid 
batch of bisoprolol fumarate EPCRS supplied by EDQM.

Bisoprolol film-coated tablets $(2.5 \mathrm{mg})$ were from ReplekFarm, Skopje.

\subsection{Preparation of test solutions and samples}

For the preparation of the test solution, 25 $\mathrm{mg}$ of bisoprolol fumarate was measured and transferred to a $25 \mathrm{ml}$ volumetric flask. Then, $20 \mathrm{ml}$ of solvent $(20 \%$ acetonitrile in water, $V / V)$ was added into the volumetric flask, mixed for about $15 \mathrm{~min}$ on a shaker, and filled up to the volume with the same solvent.

Reference solution (a) was prepared by dilution of $1 \mathrm{ml}$ of the test solution to $100 \mathrm{ml}$ with the solvent and an additional dilution of $2 \mathrm{ml}$ of this diluted solution to $10 \mathrm{ml}$ with the solvent.

Bisoprolol for peak identification was prepared by dissolving the content of the vial for peak identification chemical reference standard (CRS) in $1 \mathrm{ml}$ of solvent. Bisoprolol for peak identification contains fumaric acid, bisoprolol impurity A, bisoprolol, and bisoprolol impurity $\mathrm{E}$ (mentioned in the order they appear in the chromatogram).

Bisoprolol for system suitability was prepared by dissolving the content of the vial for or system suitability CRS in $1 \mathrm{ml}$ of solvent. Bisoprolol for system suitability contains fumaric acid, bisoprolol, and bisoprolol impurity $\mathrm{G}$ (mentioned in the order they appear in the chromatogram).

Forced degradation studies were divided into two categories: hydrolytic (acid, base, oxidative, and neutral) and the second group includes thermal degradation and exposure to moisture and light [12].

Hydrolytic forced degradation studies were performed on the powdered tablet mass and placebo powder in the presence of $1 \mathrm{M}$ hydrochloric acid, $1 \mathrm{M}$ sodium hydroxide, and $3 \%(V / V)$ hydrogen peroxide. Prepared solutions were put in an ultrasonic water bath at $60{ }^{\circ} \mathrm{C}$ for $1 \mathrm{~h}$ for acid hydrolysis and $3 \mathrm{~h}$ for the other tests. After that, the samples were cooled and neutralized and were then analysed according to the described analytical procedure.

Thermal degradation studies were performed by placing the samples of the powdered tablet and placebo powder in an open quartz dish and keeping them at $105^{\circ} \mathrm{C}$ for $5 \mathrm{~h}$ in an oven with temperature control [12]. After the prescribed period, the samples were analysed according to the described analytical procedure.
Photodegradation studies were performed by exposing the samples to UV radiation and heat in special chambers (according to ICH recommended photostability conditions) with an overall illumination of not less than 1.2 million lux $\mathrm{h}$ along with an UV energy not less than $200 \mathrm{~W} \mathrm{~h} / \mathrm{m}^{2}$. The samples of the powdered tablet and placebo powder were put in an open quartz dish and kept for a period of 10 days in the chamber. After the prescribed period, the samples were analysed according to the described analytical procedure $[12,13]$.

\subsection{HPLC analyses}

Three different HPLC/DAD systems were used for the analyses, the UPLC System Shimadzu Nexera XR LabSolution, UPLC System Shimadzu Nexera XR-4 LabSolution, and UPLC System Shimadzu Nexera-I LC 2040C 3D PlusLabSolution version 5.97. The first two are modular systems, and the third one is integrated. They have the same light source (deuterium and tungsten lamps), wavelength range and accuracy, bandwidth, and slit width. They differ in the number of diodes, slightly in the noise and drift, as well as the cell volume, characteristics that go in favour of the integrated system. Also, there are differences in the dead and dwell volume that can affect the separation and are important for the gradient method development, so systems with different dead and dwell volumes are suitable for the evaluation of the method transfer during the optimization of the separation.

Columns that are listed below were used during the method development, and some of them were later used for the method validation: RP Select B $125 \times 4.6 \mathrm{~mm}, 5 \mu \mathrm{m}$ (Merck KGaA, Darmstadt, Germany), RP Select B $250 \times 4.6 \mathrm{~mm}, 5 \mu \mathrm{m}$ (Merck KGaA, Darmstadt, Germany), Discovery C8 $150 \times 4.6 \mathrm{~mm}, 5 \mu \mathrm{m}$ (Sigma Aldrich, Bellefonte, USA), Supelco LC-DB-8 $150 \times 4 \mathrm{~mm}, 5 \mu \mathrm{m}$ (Sigma Aldrich, Bellefonte, USA), Zorbax XDB C18 $150 \times 4.6 \mathrm{~mm}, 5 \mu \mathrm{m}$ (Agilent Technologies, USA), PhenylHexyl $100 \times 4 \mathrm{~mm}, 5 \mu \mathrm{m}$ (Phenomenex, USA), Perfect Chrom 100 C8 $150 \times 4.6$ mm, $3 \mu \mathrm{m}$ (MZ Analysentechnik, Mainz, Germany), Hypersil 3 BDS C18 $100 \times 4.0$ mm, $3 \mu \mathrm{m}$, Zorbax SB C18 $150 \times 4.6 \mathrm{~mm}, 3.5 \mu \mathrm{m}$ (Agilent Technologies, USA), Aquity UPLC BEH C18 $50 \times 2.1 \mathrm{~mm}$, $1.7 \mu \mathrm{m}$ (Waters, Milford, Massachusetts, USA), and Xterra MS C18 $100 \times 4.6 \mathrm{~mm}, 3.5 \mu \mathrm{m}$ (Waters, Milford, Massachusetts, USA). Their main properties are compared in Table 1. 
Table 1

Overview of stationary phase characteristics that were tested in the method development

\begin{tabular}{|c|c|c|c|c|c|c|c|c|c|}
\hline Column & $\begin{array}{l}\text { Matrix } \\
\text { type }\end{array}$ & $\begin{array}{c}\text { Particle } \\
\text { size } \\
(\mu \mathrm{m})\end{array}$ & $\begin{array}{c}\text { Pore size } \\
\text { (á) }\end{array}$ & $\begin{array}{c}\text { Active } \\
\text { surface } \\
\mathrm{m}^{2} / \mathrm{g}\end{array}$ & $\begin{array}{c}\text { Carbon } \\
\text { load } \\
(\%)\end{array}$ & $\begin{array}{l}\text { End- } \\
\text { capped }\end{array}$ & $\begin{array}{c}\text { Base } \\
\text { deactivated }\end{array}$ & $\begin{array}{c}\text { Separation } \\
\text { efficacy } \\
\text { (plates/m) }\end{array}$ & $\mathrm{pH}$ range \\
\hline $\begin{array}{l}\text { RP Select B } \\
125 \times 4.6 \mathrm{~mm}\end{array}$ & $\begin{array}{l}\text { L7 } \\
\text { (octyl) }\end{array}$ & $5 \mu \mathrm{m}$ & $60 \dot{A}$ & $360 \mathrm{~m}^{2} / \mathrm{g}$ & $11.5 \%$ & yes & yes & 55000 & $2-7.5$ \\
\hline $\begin{array}{l}\text { RP Select B } \\
250 \times 4.6 \mathrm{~mm}\end{array}$ & $\begin{array}{l}\text { L7 } \\
\text { (octyl) }\end{array}$ & $5 \mu \mathrm{m}$ & $60 \dot{A}$ & $360 \mathrm{~m}^{2} / \mathrm{g}$ & $11.5 \%$ & yes & yes & 55000 & $2-7.5$ \\
\hline $\begin{array}{l}\text { Discovery C8 } \\
150 \times 4.6 \mathrm{~mm}\end{array}$ & $\begin{array}{l}\text { L7 } \\
\text { (octyl) }\end{array}$ & $5 \mu \mathrm{m}$ & $180 \dot{A}$ & $200 \mathrm{~m}^{2} / \mathrm{g}$ & $7.5 \%$ & yes & yes & 80000 & $2-8$ \\
\hline $\begin{array}{l}\text { Supelco LC-DB-8 } \\
150 \times 4 \mathrm{~mm}\end{array}$ & $\begin{array}{l}\text { L7 } \\
\text { (octyl) }\end{array}$ & $5 \mu \mathrm{m}$ & $120 \dot{A}$ & $170 \mathrm{~m}^{2} / \mathrm{g}$ & $6 \%$ & yes & yes & 94567 & $2-7.5$ \\
\hline $\begin{array}{l}\text { PhenylHexyl } \\
100 \times 4.6 \mathrm{~mm}\end{array}$ & $\begin{array}{l}\text { L11 } \\
\text { (phenyl-hexyl) }\end{array}$ & $5 \mu \mathrm{m}$ & $100 \dot{A}$ & $300 \mathrm{~m}^{2} / \mathrm{g}$ & $15 \%$ & yes & yes & 170000 & $1-10$ \\
\hline $\begin{array}{l}\text { Perfect Chrom } 100 \mathrm{C} 8 \\
150 \times 4.6 \mathrm{~mm}\end{array}$ & $\begin{array}{l}\text { L7 } \\
\text { (octyl) }\end{array}$ & $3 \mu \mathrm{m}$ & $100 \dot{\mathrm{A}}$ & $340 \mathrm{~m}^{2} / \mathrm{g}$ & $12 \%$ & yes & yes & 152146 & $2-8$ \\
\hline $\begin{array}{l}\text { Zorbax Eclipse XDB } \\
\mathrm{C} 18150 \times 4.6 \mathrm{~mm}\end{array}$ & $\begin{array}{l}\text { L1 } \\
\text { (octadecyl) }\end{array}$ & $5 \mu \mathrm{m}$ & $80 \dot{A}$ & $180 \mathrm{~m}^{2} / \mathrm{g}$ & $10 \%$ & yes & yes & 89286 & $2.5-9$ \\
\hline $\begin{array}{l}\text { Hypersil 3 BDS C18 } \\
100 \times 4.0 \mathrm{~mm}\end{array}$ & $\begin{array}{l}\text { L1 } \\
\text { (octadecyl) }\end{array}$ & $3 \mu \mathrm{m}$ & $130 \dot{A}$ & $170 \mathrm{~m}^{2} / \mathrm{g}$ & $11 \%$ & yes & yes & 130000 & $2-9$ \\
\hline $\begin{array}{l}\text { Zorbax SB C18 } \\
150 \times 4.6 \mathrm{~mm}\end{array}$ & $\begin{array}{l}\text { L1 } \\
\text { (octadecyl) }\end{array}$ & $3.5 \mu \mathrm{m}$ & $80 \dot{A}$ & $180 \mathrm{~m}^{2} / \mathrm{g}$ & $10 \%$ & yes & yes & 154186 & $0.8-8$ \\
\hline $\begin{array}{l}\text { Aquity UPLC BEH } \\
\text { C18 } 50 \times 2.1 \mathrm{~mm}\end{array}$ & $\begin{array}{l}\text { L1 } \\
\text { (octadecyl) }\end{array}$ & $1.7 \mu \mathrm{m}$ & $130 \dot{A}$ & $185 \mathrm{~m}^{2} / \mathrm{g}$ & $18 \%$ & yes & yes & 200000 & $2-12$ \\
\hline $\begin{array}{l}\text { Xterra MS C18 } \\
100 \times 4.6 \mathrm{~mm}\end{array}$ & $\begin{array}{l}\text { L1 } \\
\text { (octadecyl) }\end{array}$ & $3.5 \mu \mathrm{m}$ & $125 \dot{A}$ & $175 \mathrm{~m}^{2} / \mathrm{g}$ & $16 \%$ & yes & yes & 140000 & $1-12$ \\
\hline
\end{tabular}

Mobile phases that were tested consisted of acetonitrile and different buffer solutions, such as a phosphate buffer with $\mathrm{pH} 2.8$ or $\mathrm{pH} 3.0$, with 1hexanesulfonic acid sodium salt, 1-heptanesulfonic acid sodium salt, potassium hexafluorophosphate, perchloric acid, or propylamine added.

\section{RESULTS AND DISCUSSION}

\subsection{Method development and optimization}

The main goal in the method development was to achieve an efficient separation of bisoprolol fumarate from the related substances listed as requirements for related substances in the monograph for bisoprolol fumarate in the British Pharmacopoeia [4]. More precisely, the aim was to separate bisoprolol impurity $\mathrm{A}, \mathrm{G}$, and $\mathrm{E}$ from each other as well as from bisoprolol and fumaric acid. The starting point and the greatest challenge was the separation of the closely eluting peaks of bisoprolol fumarate and bisoprolol impurity G. Another important point was the separation, with a satisfactory resolution, of bisoprolol impurity A from the front in which fumaric acid is eluted. Also, last but not least was the elution of bisoprolol impurity E, which appeared to be more strongly retained and showed peak splitting. The three mentioned related substances and the active substance share an analogous structure with an aromatic ring with similar side chains (Fig. 1), which makes their separation challenging.

The first step was selection of a buffer solution with an appropriate $\mathrm{pH}$ value. The main factors in choosing the mobile phase $\mathrm{pH}$ were the $\mathrm{p} K_{\mathrm{a}}$ values for bisoprolol fumarate: $\mathrm{p} K_{\mathrm{a} 1}=9.27$ that refers to the secondary amine, and $\mathrm{p} K_{\mathrm{a} 2}=14.09$ for the alcohol moiety [14]. When selecting the suitable $\mathrm{pH}$ value for the mobile phase, $\mathrm{pH}$ values close to the $\mathrm{p} K_{\mathrm{a}}$ values (at least \pm 2 ) are avoided; $\mathrm{pH}-2$ units and $\mathrm{pH}+2$ units from the $\mathrm{p} K_{\mathrm{a}}$ for acidic and basic compounds, respectively, are recommended [15]. So, the strategy was to use a phosphate buffer with a $\mathrm{pH}$ value below the $\mathrm{p} K_{\mathrm{a}}$ values. Silica-based packaging that are presented in Table 1 have a $\mathrm{pH}$ range, in most cases, between 2 and 7. Below pH 2 , linkage of the bonded phase is prone to hydrolytic cleavage, and above $\mathrm{pH} 7$, the silica substrate is prone to dissolution. Basic compounds may show peak asymmetry at a $\mathrm{pH}$ above 3.0 as a result of the secondary interactions between the ionized form of the analyte and the accessible residual silanol groups [15]. Since acetonitrile was used in the mobile phase in most of the tested experimental cases, the $\mathrm{pH}$ of the phosphate buffer was adjusted 
to be under 3.0 in some of the experiments because acetonitrile in the mobile phase is responsible for a slight increase in the $\mathrm{pH}$ of the mobile phase mixture. Dissociation of the silanol OH-groups at $\mathrm{pH}>$
3.0 may also lead to an increased interaction with the analytes and cause peak tailing. Another benefit of using a phosphate buffer is its UVtransparency and low cut-off wavelength [15].<smiles>CC(C)NCC(O)COc1ccc(COCCOC(C)C)cc1</smiles><smiles>CC(C)NCC(O)COc1ccc(CO)cc1</smiles>

bisoprolol impurity A<smiles>CC(C)NCC(O)COc1ccc(COCCOC(C)C)cc1</smiles>

bisoprolol impurity G<smiles>CC(C)NCC=COc1ccc(COCCOC(C)C)cc1</smiles>

bisoprolol impurity E

Fig. 1. Chemical structures of bisoprolol, bisoprolol impurity A, bisoprolol impurity G, and bisoprolol impurity E

In addition to using a phosphate buffer with a pH of about 3.0 or slightly below, other mobile phase additives were tested in order to achieve better results for system suitability parameters in terms of: obtaining a good resolution of fumaric acid and bisoprolol impurity $\mathrm{A}$ as well as for bisoprolol and bisoprolol impurity $\mathrm{G}$ and also a welldefined and sharp peak for bisoprolol impurity $\mathrm{E}$. Additives that were tested were amines, ion-pair agents with a different length of the side chain, and "chaotropic" anions.

The mechanisms of action of the ion-pair agents suggest the formation of neutral pairs with the tested analytes at a certain $\mathrm{pH}$ value of the buffer solution that increases the retention and improves the separation of the tested analytes [15]. Moreover, the addition of amphiphilic ions in the mobile phase causes a transformation of the matrix into a pseudo ion-exchange surface. Amphiphilic ions are molecules with a long alkyl chain and a charged group. Most probably, two different recently investigated mechanisms take part during the separation, one being the adsorption of the amphiphilic counter ion on the stationary phase and the other being the formation of ion pairs between the analyte and the amphiphilic counter ion. The primary role of using ion-pair agents in RP-HPLC is to increase the retention by intensifying the interactions of the analytes with the stationary phase, thus altering the selectivity and improving the separation [15].

Small inorganic ions with the ability for dispersive interactions are another type of mobile phase modifier. Their mechanism of action is based on charge delocalization, which is responsible for their ability to disrupt the water solvation shell of the analytes that introduces chaos into the organized ionic solution. The process of disruption of the solvation shell is accompanied by exposure of the more hydrophobic parts of the analyte molecules to interactions with side chains of the stationary phase, thus increasing their retention [15]. The solvation shells of the analytes are responsible for the suppression and reduction of the interactions of the analyte with the stationary phase, causing their fast elution. The use of "chaotropic" ions is beneficial when the tested analytes contain a nitrogen atom (primary, secondary, or tertiary) in their structure, i.e., when tested analytes are weak basic compounds. It is also important to mention that the action of "chaotropic" ions is much more manifested in an acidic $\mathrm{pH}$ and in the presence of acetonitrile $(25-40 \% V / V)$ in the mobile phase and much less in the presence of methanol [15]. 
Another very important issue during the method development was the right choice of stationary phase matrices. Many types of stationary phases were tested, starting with C8 and $\mathrm{C} 18$ and also phenyl matrices (all tested columns with their characteristics are given in Table 1). Column temperature also has a significant impact on retention times and resolution, and a rule of thumb for reversed-phase isocratic separations is that a $1{ }^{\circ} \mathrm{C}$ increase in the column temperature decreases the $k$ value by about $2 \%$ [16]. Temperature control strongly affects the selectivity and specificity, especially for critical separations with resolution values below 2 [16]. Generally, lowering the column temperature has been shown to improve the resolution, as it was observed for the critical pair 2 (bisoprolol and bisoporlol impurity G).

All performed experiments using different columns, mobile phases, and elution parameters in the optimization of the separation are explained in detail in Table 2.

Table 2

\section{Overview of all experiments using different columns and elution profiles with critical remarks for the obtained results}

\begin{tabular}{|c|c|c|c|}
\hline $\begin{array}{l}\text { Stationary } \\
\text { phase }\end{array}$ & Mobile phase & $\begin{array}{l}\text { Flow rate } \\
\text { and tempera- } \\
\text { ture }\end{array}$ & Remarks \\
\hline $\begin{array}{l}\text { RP Select B } \\
250 \times 4.6 \\
\mathrm{~mm}, 5 \mu \mathrm{m}\end{array}$ & $30 \%$ acetonitrile : $70 \% 25 \mathrm{mM}$ phosphate buffer $\mathrm{pH} 2.8$ & $\begin{array}{l}1.2 \mathrm{ml} / \mathrm{min} \\
30^{\circ} \mathrm{C}\end{array}$ & $\begin{array}{l}\text { No separation of critical pair } 2 \\
\text { (bisoprolol and bisoprolol impurity } \mathrm{G} \text { ). }\end{array}$ \\
\hline \multirow{7}{*}{$\begin{array}{l}\text { RP Select B } \\
125 \times 4.6 \\
\mathrm{~mm}, 5 \mu \mathrm{m}\end{array}$} & $30 \%$ acetonitrile : $70 \% 25 \mathrm{mM}$ phosphate buffer $\mathrm{pH} 2.8$ & $\begin{array}{l}1.2 \mathrm{ml} / \mathrm{min} \\
30^{\circ} \mathrm{C}\end{array}$ & No separation of critical pairs. \\
\hline & $25 \%$ acetonitrile : $75 \% 25 \mathrm{mM}$ phosphate buffer $\mathrm{pH} 2.8$ & $\begin{array}{l}1.2 \mathrm{ml} / \mathrm{min} \\
30^{\circ} \mathrm{C}\end{array}$ & No separation of critical pairs. \\
\hline & $\begin{array}{l}25 \% \text { acetonitrile : } 75 \% 10 \mathrm{mM} \text { phosphate buffer } \mathrm{pH} 2.8 \text { with } \\
\text { added } 0.22 \%(\mathrm{w} / \mathrm{v}) \text { 1-hexanesulfonic acid sodium salt }\end{array}$ & $\begin{array}{l}1.2 \mathrm{ml} / \mathrm{min} \\
20^{\circ} \mathrm{C}\end{array}$ & $\begin{array}{l}\text { No separation of critical pair } 2 \\
\text { (bisoprolol and bisoprolol impurity G). }\end{array}$ \\
\hline & $\begin{array}{l}25 \% \text { acetonitrile : } 5 \% \text { methanol : } 70 \% 10 \mathrm{mM} \text { phosphate buff- } \\
\text { er pH } 2.8 \text { with } 0.22 \%(\mathrm{w} / \mathrm{v}) \text { 1-hexanesulfonic acid sodium salt }\end{array}$ & $\begin{array}{l}1.2 \mathrm{ml} / \mathrm{min} \\
20^{\circ} \mathrm{C}\end{array}$ & $\begin{array}{l}\text { No separation of critical pair } 2 \\
\text { (bisoprolol and bisoprolol impurity G). }\end{array}$ \\
\hline & $\begin{array}{l}20 \% \text { acetonitrile : } 80 \% 10 \mathrm{mM} \text { phosphate buffer } \mathrm{pH} 2.8 \text { with } \\
\text { added } 0.22 \%(\mathrm{w} / \mathrm{v}) \text { 1-hexanesulfonic acid sodium salt }\end{array}$ & $\begin{array}{l}1.2 \mathrm{ml} / \mathrm{min} \\
20^{\circ} \mathrm{C}\end{array}$ & $\begin{array}{l}\text { No separation of critical pair } 2 \\
\text { (bisoprolol and bisoprolol impurity } \mathrm{G} \text { ). } \\
\text { Wide peak of bisoprolol. }\end{array}$ \\
\hline & $\begin{array}{l}25 \% \text { acetonitrile : } 75 \% 10 \mathrm{mM} \text { phosphate buffer } \mathrm{pH} 2.8 \text { with } \\
\text { added } 0.25 \%(\mathrm{w} / \mathrm{v}) \text { 1-heptansulfonic acid sodium salt }\end{array}$ & $\begin{array}{l}1.2 \mathrm{ml} / \mathrm{min} \\
20^{\circ} \mathrm{C}\end{array}$ & $\begin{array}{l}\text { No separation of critical pair } 2 \\
\text { (bisoprolol and bisoprolol impurity G). }\end{array}$ \\
\hline & $\begin{array}{l}30 \% \text { acetonitrile : } 70 \% 10 \mathrm{mM} \text { phosphate buffer } \mathrm{pH} 2.8 \text { with } \\
\text { added } 0.25 \%(\mathrm{w} / \mathrm{v}) \text { 1-heptansulfonic acid sodium salt }\end{array}$ & $\begin{array}{l}1.2 \mathrm{ml} / \mathrm{min} \\
20^{\circ} \mathrm{C}\end{array}$ & $\begin{array}{l}\text { No separation of critical pair } 2 \\
\text { (bisoprolol and bisoprolol impurity G). }\end{array}$ \\
\hline \multirow{2}{*}{$\begin{array}{l}\text { Discovery C8 } \\
150 \times 4.6 \\
\mathrm{~mm}, 5 \mu \mathrm{m}\end{array}$} & $\begin{array}{l}30 \% \text { acetonitrile : } 70 \% 10 \mathrm{mM} \text { phosphate buffer } \mathrm{pH} 3.0 \text { with } \\
\text { added } 0.15 \%(\mathrm{w} / \mathrm{v}) \text { potassium hexafluorophosphate }\end{array}$ & $\begin{array}{l}1.2 \mathrm{ml} / \mathrm{min} \\
30^{\circ} \mathrm{C}\end{array}$ & $\begin{array}{l}\text { No separation of critical pair } 2 \\
\text { (bisoprolol and bisoprolol impurity G). }\end{array}$ \\
\hline & $\begin{array}{l}25 \% \text { acetonitrile : } 75 \% 10 \mathrm{mM} \text { phosphate buffer } \mathrm{pH} 3.0 \text { with } \\
\text { added } 0.30 \%(\mathrm{w} / \mathrm{v}) \text { potassium hexafluorophosphate }\end{array}$ & $\begin{array}{l}1.2 \mathrm{ml} / \mathrm{min} \\
30^{\circ} \mathrm{C}\end{array}$ & $\begin{array}{l}\text { No separation of critical pair } 2 \\
\text { (bisoprolol and bisoprolol impurity G). }\end{array}$ \\
\hline \multirow{2}{*}{$\begin{array}{l}\text { Supelco LC- } \\
\text { DB-8 } \\
150 \times 4 \mathrm{~mm} \text {, } \\
5 \mu \mathrm{m}\end{array}$} & $\begin{array}{l}27 \% \text { acetonitrile }: 73 \% 10 \mathrm{mM} \text { phosphate buffer with added } \\
0.2 \%(\mathrm{w} / \mathrm{v}) \text { potassium hexafluorophosphate, } 0.7 \%(\mathrm{v} / \mathrm{v}) \text { per- } \\
\text { chloric acid, } 0.76 \%(\mathrm{v} / \mathrm{v}) \text { propylamin, adjusted to } \mathrm{pH} 2.8\end{array}$ & $\begin{array}{l}1.2 \mathrm{ml} / \mathrm{min} \\
30^{\circ} \mathrm{C}\end{array}$ & $\begin{array}{l}\text { No separation of critical pair } 2 \\
\text { (bisoprolol and bisoprolol impurity } \mathrm{G}) \text {. }\end{array}$ \\
\hline & $\begin{array}{l}22 \% \text { acetonitrile : } 78 \% 10 \mathrm{mM} \text { phosphate buffer with added } \\
0.2 \%(\mathrm{w} / \mathrm{v}) \text { potassium hexafluorophosphate, } 0.7 \%(\mathrm{v} / \mathrm{v}) \text { per- } \\
\text { chloric acid, } 0.76 \%(\mathrm{v} / \mathrm{v}) \text { propylamin, adjusted to } \mathrm{pH} 2.8\end{array}$ & $\begin{array}{l}1.2 \mathrm{ml} / \mathrm{min} \\
30^{\circ} \mathrm{C}\end{array}$ & $\begin{array}{l}\text { No separation of critical pair } 2 \\
\text { (bisoprolol and bisoprolol impurity G). } \\
\text { Splitted peak of bisoprolol impurity E. }\end{array}$ \\
\hline \multirow{5}{*}{$\begin{array}{l}\text { Perfect } \\
\text { Chrom } 100 \\
\text { C8 } \\
150 \times 4.6 \\
\mathrm{~mm}, 3 \mu \mathrm{m}\end{array}$} & $\begin{array}{l}30 \% \text { acetonitrile : } 70 \% 10 \mathrm{mM} \text { phosphate buffer } \mathrm{pH} 3.0 \text { with } \\
\text { added } 0.2 \%(\mathrm{w} / \mathrm{v}) \text { potassium hexafluorophosphate }\end{array}$ & $\begin{array}{l}0.9 \mathrm{ml} / \mathrm{min} \\
20^{\circ} \mathrm{C}\end{array}$ & $\begin{array}{l}\text { Satisfying separation of both critical pairs, but } \\
\text { very late elution. Not in line with the intention } \\
\text { of shortening the run time length. }\end{array}$ \\
\hline & $\begin{array}{l}37 \% \text { acetonitrile : } 63 \% 10 \mathrm{mM} \text { phosphate buffer } \mathrm{pH} 3.0 \text { with } \\
\text { added } 0.2 \%(\mathrm{w} / \mathrm{v}) \text { potassium hexafluorophosphate }\end{array}$ & $\begin{array}{l}0.9 \mathrm{ml} / \mathrm{min} \\
20^{\circ} \mathrm{C}\end{array}$ & $\begin{array}{l}\text { No separation of critical pair } 2 \\
\text { (bisoprolol and bisoprolol impurity G). }\end{array}$ \\
\hline & $\begin{array}{l}40 \% \text { acetonitrile : } 60 \% 10 \mathrm{mM} \text { phosphate buffer } \mathrm{pH} 3.0 \text { with } \\
\text { added } 0.2 \%(\mathrm{w} / \mathrm{v}) \text { potassium hexafluorophosphate }\end{array}$ & $\begin{array}{l}0.9 \mathrm{ml} / \mathrm{min} \\
20^{\circ} \mathrm{C}\end{array}$ & $\begin{array}{l}\text { No separation of critical pair } 2 \\
\text { (bisoprolol and bisoprolol impurity G). }\end{array}$ \\
\hline & $\begin{array}{l}45 \% \text { acetonitrile }: 55 \% 10 \mathrm{mM} \text { phosphate buffer } \mathrm{pH} 3.0 \text { with } \\
\text { added } 0.2 \%(\mathrm{w} / \mathrm{v}) \text { potassium hexafluorophosphate }\end{array}$ & $\begin{array}{l}0.9 \mathrm{ml} / \mathrm{min} \\
20^{\circ} \mathrm{C}\end{array}$ & $\begin{array}{l}\text { No separation of critical pair } 2 \\
\text { (bisoprolol and bisoprolol impurity G). }\end{array}$ \\
\hline & $\begin{array}{l}35 \% \text { acetonitrile }: 5 \% \text { methanol : } 60 \% 10 \mathrm{mM} \text { phosphate } \\
\text { buffer } \mathrm{pH} 3.0 \text { with added } 0.2 \%(\mathrm{w} / \mathrm{v}) \text { potassium hexafluoro- } \\
\text { phosphate }\end{array}$ & $\begin{array}{l}0.9 \mathrm{ml} / \mathrm{min} \\
20^{\circ} \mathrm{C}\end{array}$ & $\begin{array}{l}\text { No separation of critical pair } 2 \\
\text { (bisoprolol and bisoprolol impurity } \mathrm{G}) \text {. }\end{array}$ \\
\hline \multirow{2}{*}{$\begin{array}{l}\text { PhenylHexyl } \\
100 \times 4 \mathrm{~mm} \text {, } \\
5 \mu \mathrm{m}\end{array}$} & $30 \%$ acetonitrile : $70 \% 10 \mathrm{mM}$ phosphate buffer $\mathrm{pH} 2.8$ & $\begin{array}{l}1.0 \mathrm{ml} / \mathrm{min} . \\
20^{\circ} \mathrm{C}\end{array}$ & No separation of critical pairs. \\
\hline & $\begin{array}{l}30 \% \text { acetonitrile }: 70 \% 10 \mathrm{mM} \text { phosphate buffer } \mathrm{pH} 2.8 \text { with } \\
\text { added } 0.3 \%(\mathrm{w} / \mathrm{v}) \text { potassium hexafluorophosphate }\end{array}$ & $\begin{array}{l}1.0 \mathrm{ml} / \mathrm{min} . \\
20^{\circ} \mathrm{C}\end{array}$ & $\begin{array}{l}\text { Obtained resolution of critical pair } 2 \text { (bisoprolol } \\
\text { and bisoprolol impurity G) } 1.91 \text {. Not enough for } \\
\text { peaks with big differences in peak area. }\end{array}$ \\
\hline
\end{tabular}


Table 2 continues

\begin{tabular}{|c|c|c|c|}
\hline & $\begin{array}{l}30 \% \text { acetonitrile }: 5 \% \text { methanol : } \\
65 \% 10 \mathrm{mM} \text { phosphate buffer } \mathrm{pH} 2.8 \text { with added } 0.3 \%(\mathrm{w} / \mathrm{v}) \\
\text { potassium hexafluorophosphate }\end{array}$ & $\begin{array}{l}1.0 \mathrm{ml} / \mathrm{min} \\
20^{\circ} \mathrm{C}\end{array}$ & $\begin{array}{l}\text { No separation of critical pair } 2 \\
\text { (bisoprolol and bisoprolol impurity G). }\end{array}$ \\
\hline \multirow{2}{*}{$\begin{array}{l}\text { Zorbax XDB } \\
\text { C18 } \\
150 \times 4.6 \\
\mathrm{~mm}, 5 \mu \mathrm{m}\end{array}$} & $\begin{array}{l}30 \% \text { acetonitrile : } 70 \% 10 \mathrm{mM} \text { phosphate buffer } \mathrm{pH} 3.0 \text { with } \\
\text { added } 0.3 \%(\mathrm{w} / \mathrm{v}) \text { potassium hexafluorophosphate }\end{array}$ & $\begin{array}{l}1.2 \mathrm{ml} / \mathrm{min} \\
30{ }^{\circ} \mathrm{C}\end{array}$ & $\begin{array}{l}\text { Obtained resolution of critical pair } 2 \text { (bisopro- } \\
\text { lol and bisoprolol impurity G) } 1.88 \text {. Not } \\
\text { enough for peaks with big differences in peak } \\
\text { area. }\end{array}$ \\
\hline & $\begin{array}{l}35 \% \text { acetonitrile : } 65 \% 10 \mathrm{mM} \text { phosphate buffer } \mathrm{pH} 3.0 \text { with } \\
\text { added } 0.3 \%(\mathrm{w} / \mathrm{v}) \text { potassium hexafluorophosphate }\end{array}$ & $\begin{array}{l}1.2 \mathrm{ml} / \mathrm{min} \\
30{ }^{\circ} \mathrm{C}\end{array}$ & $\begin{array}{l}\text { No separation of critical pair } 2 \text { (bisoprolol and } \\
\text { bisoprolol impurity G). Splitted peak of bi- } \\
\text { soprolol impurity E. }\end{array}$ \\
\hline $\begin{array}{l}\text { Zorbax SB } \\
\text { C18 } \\
150 \times 4.6 \\
\mathrm{~mm}, 3.5 \mu \mathrm{m}\end{array}$ & $\begin{array}{l}\text { Gradient elution: } \\
0-9 \text { min: } 27 \% \text { acetonitrile; } \\
9-9.01 \text { min.: } 27 \%-60 \% \text { acetonitrile; } \\
9.01-11.5 \text { min.: } 60 \% \text { acetonitrile; } \\
11.5-11.6 \text { min: } 60 \%-27 \% \text { acetonitrile; } \\
11.6-18 \text { min: } 27 \% \text { acetonitrile } \\
\text { *inorganic part: } 0.2 \%(\mathrm{v} / \mathrm{v}) \text { perchloric acid } \\
\end{array}$ & $\begin{array}{l}1.2 \mathrm{ml} / \mathrm{min} \\
20^{\circ} \mathrm{C}\end{array}$ & $\begin{array}{l}\text { Resolution of critical pair } 1 \text { (fumaric acid and } \\
\text { bisoprolol impurity A) is } 2.3 \text {. } \\
\text { Resolution of critical pair } 2 \text { (bisoprolol and } \\
\text { bisoprolol impurity G) is } 2.4 \text {. } \\
\text { Analysis time is } 18 \mathrm{~min} \text {. }\end{array}$ \\
\hline $\begin{array}{l}\text { Hypersil } 3 \\
\text { BDS C18 } \\
100 \times 4.0 \\
\mathrm{~mm}, 3 \mu \mathrm{m}\end{array}$ & $\begin{array}{l}\text { Gradient elution: } \\
\text { 0-11.5 min: } 25 \% \text { acetonitrile; } \\
\text { 11.5-11.6 min: } 25 \%-40 \% \text { acetonitrile; } \\
\text { 11.6- } 15.5 \text { min: } 40 \% \text { acetonitrile; } \\
\text { 15.5-15.6 min: } 40 \%-25 \% \text { acetonitrile; } \\
\text { 15.6-22 min: } 25 \% \text { acetonitrile; } \\
\text { *inorganic part: } 10 \mathrm{mM} \text { phosphate buffer } \mathrm{pH} 3.0 \text { with added } \\
0.2 \% \text { (w/v) potassium hexafluorophosphate }\end{array}$ & $\begin{array}{l}1.0 \mathrm{ml} / \mathrm{min} \\
20{ }^{\circ} \mathrm{C}\end{array}$ & $\begin{array}{l}\text { Resolution of critical pair } 1 \text { (fumaric acid and } \\
\text { bisoprolol impurity A) is } 4.3 \text {. } \\
\text { Resolution of critical pair } 2 \text { (bisoprolol and } \\
\text { bisoprolol impurity G) is } 2.3 \text {. } \\
\text { Analysis time is } 22 \text { min. }\end{array}$ \\
\hline $\begin{array}{l}\text { Aquity UPLC } \\
\text { BEH C18 } \\
50 \times 2.1 \mathrm{~mm} \\
1.7 \mu \mathrm{m}\end{array}$ & $\begin{array}{l}\text { Gradient elution: } \\
\text { 0-1 min: } 15 \%-25 \% \text { acetonitrile; } \\
1-5 \text { min: } 25 \%-32 \% \text { acetonitrile; } \\
5-6 \text { min: } 32 \% \text { acetonitrile; } \\
\text { 6-7 } \min : 32 \%-45 \% \text { acetonitrile; } \\
\text { 7-9.5 min: } 45 \% \text { acetonitrile; } \\
\text { 9.5- } 10 \text { min: } 45 \%-15 \% \text { acetonitrile; } \\
10-12 \text { min: } 15 \% \text { acetonitrile } \\
\text { *inorganic part: } 0.2 \%(\mathrm{v} / \mathrm{v}) \text { perchloric acid }\end{array}$ & $\begin{array}{l}0.23 \mathrm{ml} / \mathrm{min} \\
20^{\circ} \mathrm{C}\end{array}$ & $\begin{array}{l}\text { Resolution of critical pair } 1 \text { (fumaric acid and } \\
\text { bisoprolol impurity A) is } 5.6 \text {. } \\
\text { Resolution of critical pair } 2 \text { (bisoprolol and } \\
\text { bisoprolol impurity G) is } 2.4 \text {. } \\
\text { Analysis time is } 12 \text { min. } \\
\text { High column backpressure. }\end{array}$ \\
\hline $\begin{array}{l}\text { Xterra MS } \\
\text { C18 } \\
100 \times 4.6 \\
\mathrm{~mm}, 3.5 \mu \mathrm{m}\end{array}$ & $\begin{array}{l}\text { Gradient elution: } \\
\text { 0-1 min: } 22 \% \text { acetonitrile; } \\
1-2 \text { min: } 22 \%-26 \% \text { acetonitrile; } \\
2-6 \text { min: } 26 \% \text { acetonitrile; } \\
6-7 \text { min: } 26 \%-45 \% \text { acetonitrile; } \\
\text { 7-9.3 } \min : 45 \% \text { acetonitrile; } \\
\text { 9.3-9.5 min: } 45 \% \text { - } 22 \% \text { acetonitrile; } \\
\text { 9.5-13 min: } 22 \% \text { acetonitrile } \\
\text { *inorganic part: } 0.2 \%(\mathrm{v} / \mathrm{v}) \text { perchloric acid }\end{array}$ & $\begin{array}{l}0.23 \mathrm{ml} / \mathrm{min} \\
20^{\circ} \mathrm{C}\end{array}$ & $\begin{array}{l}\text { Resolution of critical pair } 1 \text { (fumaric acid and } \\
\text { bisoprolol impurity A) is } 2.6 \text {. } \\
\text { Resolution of critical pair } 2 \text { (bisoprolol and } \\
\text { bisoprolol impurity G) is } 2.4 \text {. } \\
\text { Analysis time is } 13 \text { min. }\end{array}$ \\
\hline
\end{tabular}

The structures of the tested molecules of bisoprolol impurity A, bisoprolol, bisoprolol impurity $\mathrm{G}$, and bisoprolol impurity $\mathrm{E}$ are very different in terms of polarity, and one can assume that it would be difficult and even impossible to separate these moieties from each other with isocratic elution. To test this option, an experiment with an initial gradient run was performed in order to make the first impressions and conclusions for the tested analytes, as a suggested first step [16]. An experiment was carried out on Xterra MS C18 $100 \times 4.6$ $\mathrm{mm}, 3.5 \mu \mathrm{m}$. A gradient elution with an increase in acetonitrile from $5 \%$ to $80 \%$ in 10 min was used. In order to decide whether it is possible to use isocratic elution or it is necessary to use gradient elution, the retention times of the first and last peaks of interest obtained with the starting gradient elution were analysed. The retention time of the first analyte was $2.2 \mathrm{~min}$ (bisoprolol impurity A), and the last analyte was eluted at $5.1 \mathrm{~min}$ (bisoprolol impurity E). To make a decision for using isocratic or gradient elution, an approximate rule was used: if $\Delta t_{\mathrm{R}} / t_{\mathrm{G}} \leq 0.25\left(t_{\mathrm{G}}=\right.$ gradient time $)$, isocratic elution is used, and if $\Delta t_{\mathrm{R}} / t_{\mathrm{G}} \geq 0.40$, gradient elution is used [16]. For intermediate values of $\Delta t_{\mathrm{R}} / t_{\mathrm{G}}$, either isocratic or gradient elution may be used. In our case, this ratio was $2.9 \mathrm{~min} / 10 \mathrm{~min}=0.29$, which implied that bisoprolol impurity A and E could be separated either with isocratic or gradient elution, but for separation of all compounds of interest, gradient elution was necessary.

When it comes to the choice of the stationary phase, the method development started with stationary phases with octyl chains in order to obtain good resolution in shorter run times and to consume less mobile phase due to the use of a lower content of organic solvents because of weaker interactions, making the method more efficient and economical. 
On the other hand, using columns with octadecyl chains for analytes with very different polarities results in separation of the analytes with longer run times and higher mobile phase consumption.

RP Select B is a very commonly used very dense bonded stationary phase with a high surface area of $360 \mathrm{~m}^{2} / \mathrm{g}$ that is end-capped and base deactivated. Results obtained from the first three trials by using a phosphate buffer adjusted to a $\mathrm{pH}$ of 2.8 showed that this type of stationary phase, besides changes in the mobile phase ratio as well as the column length, is not suitable. The peak of bisoprolol impurity A in the standard for peak identification was not detected because it coeluted with the peak of fumaric acid. Moreover, the peak of bisoprolol impurity $\mathrm{G}$ in the standard for system suitability was also not detected since it coeluted with the peak of bisoprolol. Decreasing the percentage of acetonitrile and increasing the column length did not bring significant changes in the retention times and separation of the critical pairs. Failing to obtain good separation between the tested analytes using RP Select B even for two different lengths implied that this type of stationary phase is not characterized with adequate selectivity.

To improve the separation, it was decided to introduce an ion-pair agent in the mobile phase. Since bisoprolol along with its impurities are weak bases, sodium alkanesulfonate was added to the mobile phase as a suitable ion-pair agent. The addition of both sodium salts of alkansulfonic acid improved the separation of bisoprolol impurity A from fumaric acid in the front. Better results were observed with 1-heptansulfonic acid sodium salt due to the longer alkyl-side chain. Separation between bisoprolol and bisoprolol impurity $G$ was not achieved in both cases. Chromatograms obtained with the two tested ion-pair agents on RP Select B are provided in supplementary Figures S1 and S2.

In spite of being a reversed phase with high carbon load as for the octyl phase $(11.5 \%)$ but with lower values for the number of theoretical plates (NTP/m of 55000), which is favorable during the method development, the selectivity of RP Select B was shown to be inappropriate for the separation of bisoprolol and related substances. Because of all mentioned, other types of C8 stationary phases were taken into consideration.

Discovery C8 $150 \times 4.6 \mathrm{~mm}, 5 \mu \mathrm{m}$ is a stationary phase with a low to medium active surface $\left(200 \mathrm{~m}^{2} / \mathrm{g}\right)$, one of the largest pore size of $180 \dot{\mathrm{A}}$ among $5 \mu \mathrm{m}$ particle columns, and an efficiency of $90000 \mathrm{NTP} / \mathrm{m}$ at a middle ranged octyl type carbon load. The results from these experiments showed that using this type of $\mathrm{C} 8$ phase with the same mobile phase (phosphate buffer with $\mathrm{pH} 3.0$, additives and acetonitrile) affects the retention times of the analytes of interest, and bisoprolol impurity A was separated from fumaric acid. However, the obtained chromatograms showed no separation at all between bisoprolol and bisoprolol impurity G (Fig. S3, supplementary).

Supelco LC-DB-8 $150 \times \mathbf{4} \mathbf{m m}, \mathbf{5} \boldsymbol{\mu m}$ is characterized with a lower active surface of $170 \mathrm{~m}^{2} / \mathrm{g}$, and was also tested and taken into account because it is a C8 matrix, which is deactivated. This column is less retentive due to its $6 \%$ carbon load. To improve separation and increase retention, two types of "chaotropic" agents were used, potassium hexafluorophosphate and perchloric acid combined with propylamine, which was added to improve the peak symmetry. Separation of bisoprolol impurity A from fumaric acid was not satisfactory, and bisoprolol and bisoprolol impurity $\mathrm{G}$ were not separated, whereas the peak from bisoprolol impurity $\mathrm{E}$ was eluted as well shaped peak (Fig. S4, supplementary).

Perfect Chrom 100 C8 $150 \times 4.6$ mm, 3 $\mu \mathrm{m}$ was taken into consideration because of the smaller particle size, high surface area of $340 \mathrm{~m}^{2} / \mathrm{g}$, and carbon load of $12 \%$. It also has a higher value for $\mathrm{NTP} / \mathrm{m}$ of 152146 , which was supposed to bring better separation of the tested analytes. This phase is very retentive, and the peak of bisoprolol appeared very late in the chromatogram; it was eluted at around $18 \mathrm{~min}$. Right after the peak of bisoprolol, the peak of bisoprolol impurity $\mathrm{G}$ was eluted with a resolution of about 2.0, which was good, but the run time was quite long and modification of the mobile phase was needed. Changes in the composition of the mobile phase did not allow both goals to be reached, i.e., good resolution and separation with satisfactory system suitability parameters in a reasonable length of the run time of analysis, as can be seen in the chromatograms in Figure S5 and Figure S6 (supplementary).

Another type of RP-bonded phase that was tested was PhenylHexyl $100 \times \mathbf{4 . 6} \mathbf{~ m m}, 5 \boldsymbol{\mu m}$ as a stationary phase with mobile phases containing a phosphate buffer with $\mathrm{pH} 2.8$ with $\mathrm{KPF}_{6}$ and acetonitrile added. Good separation of bisoprolol impurity A from fumaric acid was achieved. A relatively good separation of bisoprolol and bisoprolol impurity $\mathrm{G}$ was also achieved, but elution in a relatively reasonable amount of time was not achieved for bisoprolol impurity E. Addition of $\mathrm{KPF}_{6}$ increased the retention of the analytes, providing a resolution of 1.91 between the peaks of bisoprolol and bisoprolol impurity $\mathrm{G}$, but it was still not in accordance 
with the requirements due to the big difference in the peak areas of these two peaks. The addition of methanol was tested in order to change the selectivity and improve the resolution, but it did not bring satisfactory results (Fig. S7, supplementary).

Zorbax XDB C18 $150 \times 4.6 \mathrm{~mm}, 5 \mu \mathrm{m}$ is a $\mathrm{C} 18$ reverse phase matrix that was taken into consideration because of its high value for NTP/m (89286) and extra dense bonding (XDB) accomplished by adding a monolayer of C18-silane to the ultra-pure, fully-hydroxylated, ZORBAX Rx-silica surface. The mobile phase was a phosphate buffer (pH 3.0) with "chaotropic" ion $\mathrm{KPF}_{6}$ and acetonitrile added. The obtained results showed good separation of bisoprolol impurity A from fumaric acid and a resolution of 1.88 between bisoprolol and bisoprolol impurity G (Fig. S8), but elution of the bisoprolol impurity $\mathrm{E}$ was not achieved. The latter issue could be fixed by a stepwise gradient with a rapid increase in the organic part right after the elution of bisoprolol impurity $\mathrm{G}$, but it was not a reasonable approach due to the obtained resolution between bisoprolol and bisoprolol impurity G, which was less than the minimum required. Further modifications of the mobile phase composition and gradients were shown to be unsuccessful.

The next experiment to satisfy the system suitability parameters used Zorbax SB C18 $150 \times$ $4.6 \mathrm{~mm}, 3.5 \mu \mathrm{m}$ with $0.2 \%(\mathrm{v} / \mathrm{v})$ perchloric acid and acetonitrile as the mobile phase. This type of $\mathrm{RP}$-bond phase is resistant over a wider $\mathrm{pH}$ range and has a high value for NTP/m (154186). Very good resolution between bisoprolol and bisoprolol impurity $\mathrm{G}$ was obtained; the actual value was about 2.4 (Fig. 2). In order to force the elution of bisoprolol impurity E, a stepwise gradient was introduced with a fast increase in the organic part in the mobile phase that caused elution of impurity $\mathrm{E}$ at around $11 \mathrm{~min}$. This column has a higher separation power and a lower pressure drop compared to other columns with $3 \mu \mathrm{m}$ particles as well as better permeability and flow resistance.

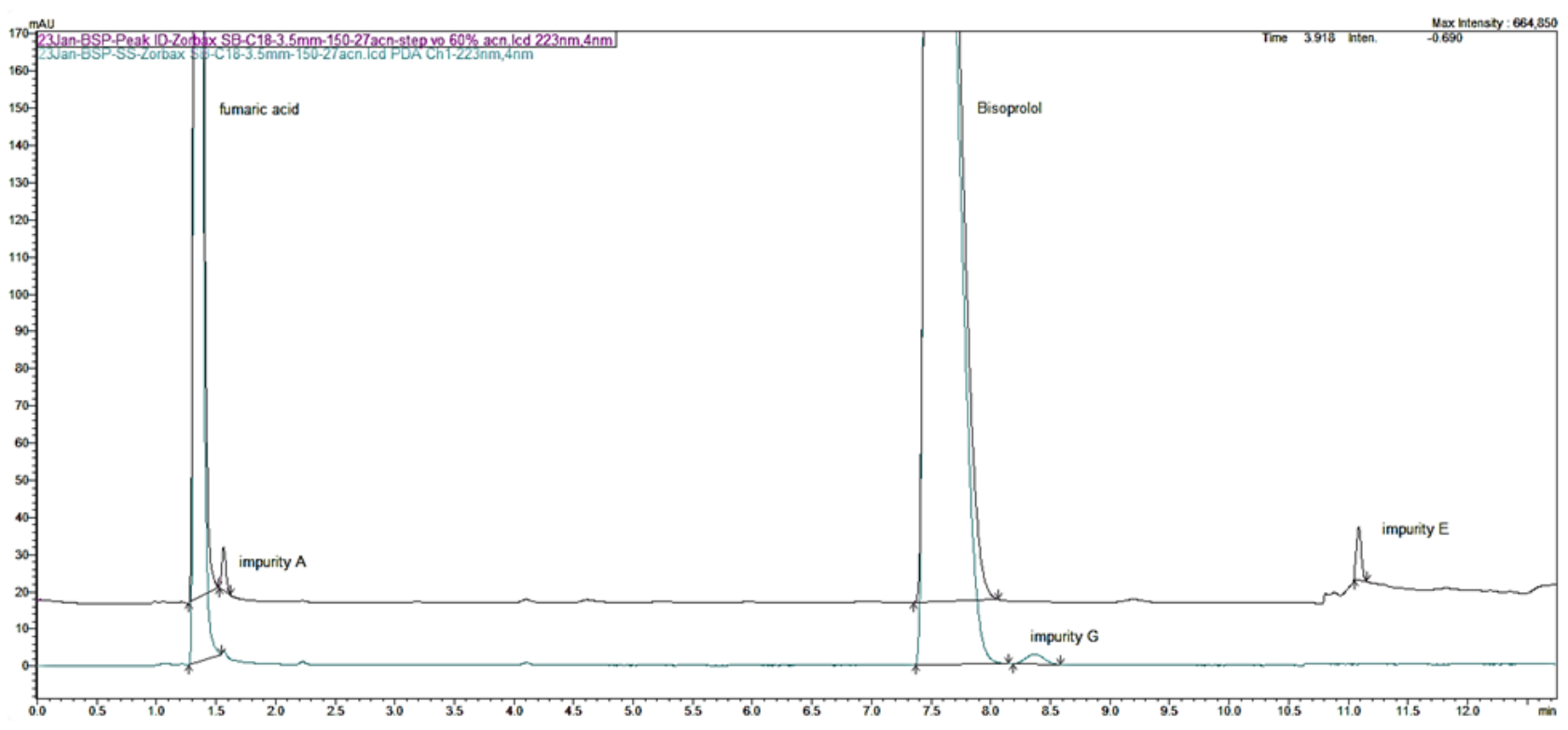

Fig. 2. Chromatograms of the solution for peak identification and the solution for system suitability obtained using Zorbax SB C18 $150 \times 4.6 \mathrm{~mm}, 3.5 \mu \mathrm{m}$, and gradient elution with acetonitrile and $0.2 \%$ (v/v) perchloric acid; $1.2 \mathrm{ml} / \mathrm{min}, 20^{\circ} \mathrm{C}$ (Table 2)

Hypersil 3 BDS C18 $100 \times 4$ mm, $3 \mu \mathrm{m}$ was taken into consideration as a matrix that is base deactivated and endcapped with a high $\mathrm{NTP} / \mathrm{m}$ of 130000 . It was used with a mobile phase consisting of a phosphate buffer with $\mathrm{pH} 3.0$ and $0.2 \%(\mathrm{w} / \mathrm{v})$ potassium hexafluorophosphate and acetonitrile. As can be seen in Figure 3, promising results were obtained that fulfill the requirements for system suitability with good separation and resolution. Bisoprolol impurity A was well separated from the front and fumaric acid and cannot be mistaken with most polar compounds that elute within the front. The peak of bisoprolol is sharp with good symmetry and well resolved from the peak of bisoprolol impurity $\mathrm{G}$ that elutes next to it, with a resolution of 2.3. The peak from bisoprolol impurity $\mathrm{E}$ is eluted in a reasonable amount of time and is also sharp with good symmetry (Fig. 3).

Literature data presented in the paper of $\mathrm{M}$. Szalka et al. [1] considered the use of columns with sub-2- $\mu \mathrm{m}$ adsorbents. More precisely, they studied the use of a broad spectrum of stationary 
phases with sub-2- $\mu \mathrm{m}$ particles, with $50 \mathrm{~mm}$ to 150 $\mathrm{mm}$ columns, and gradient elution with mobile phases consisting of methanol and phosphate buffer with $\mathrm{pH}$ 5.5. They concluded that Acquity UPLC BEH C18 $50 \times 2.1 \mathrm{~mm}, 1.7 \mu \mathrm{m}$ was not able to separate fumaric acid and impurity $\mathrm{A}$ and $\mathrm{L}$ and also impurity B and $\mathrm{G}$ were eluted in one peak, which was also partially co-eluted under the main peak of bisoprolol [1].
Taking into consideration these experiments, we supposed that a change in the $\mathrm{pH}$ of the mobile phase as well as a change in its composition could improve the separation and resolution. So, in our study, we started with an acidic mobile phase consisting of $0.06 \%(\mathrm{v} / \mathrm{v})$ perchloric acid and acetonitrile and gradient elution. Good resolution between all peaks of interest was obtained in, so far, the shortest analysis time (Fig. 4).

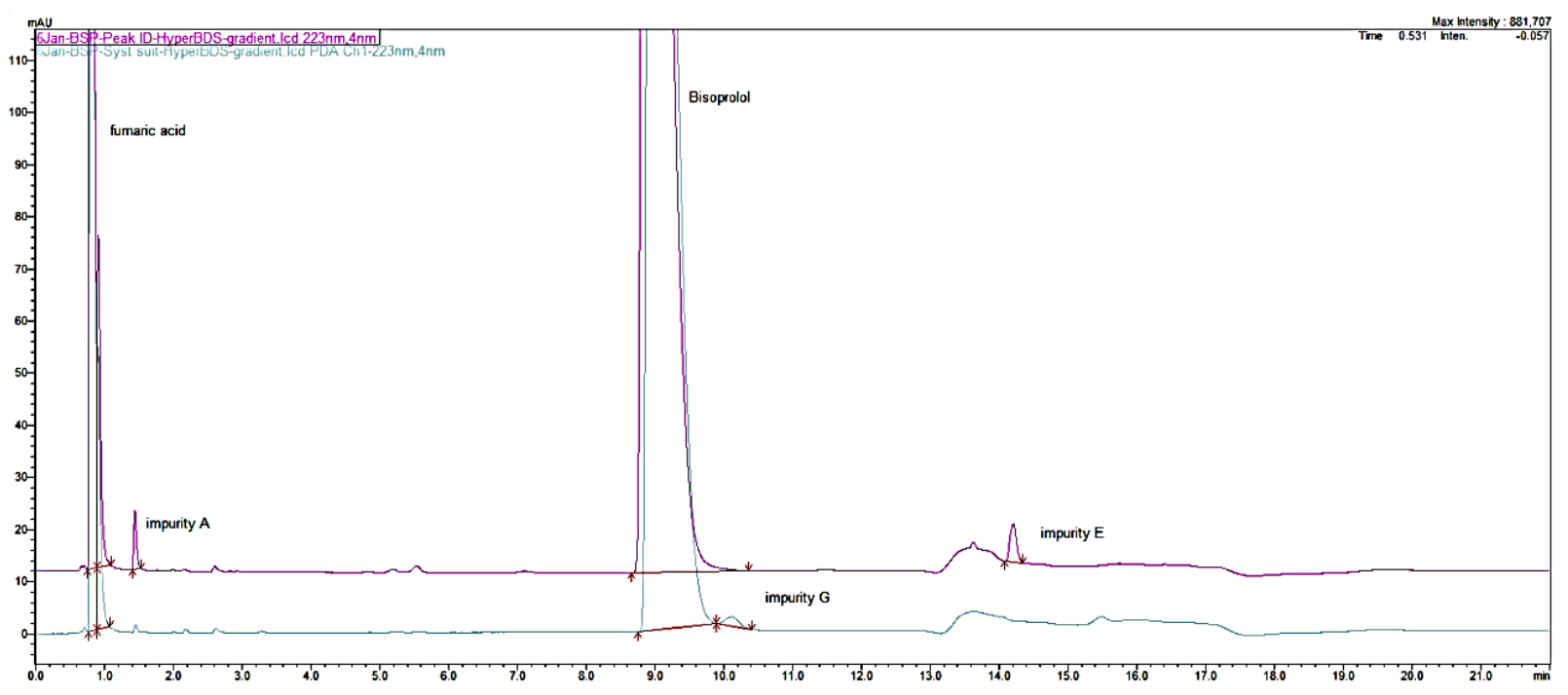

Fig. 3. Chromatograms of the solution for peak identification and the solution for system suitability obtained using Hypersil 3 BDS C18 $100 \times 4.0 \mathrm{~mm}, 3 \mu \mathrm{m}$, and gradient elution with acetonitrile and $10 \mathrm{mM}$ phosphate buffer $\mathrm{pH} 3.0$ with $0.2 \%(\mathrm{w} / \mathrm{v}) \mathrm{KPF}_{6} ; 1.0 \mathrm{ml} / \mathrm{min}, 20{ }^{\circ} \mathrm{C}$ (Table 2)

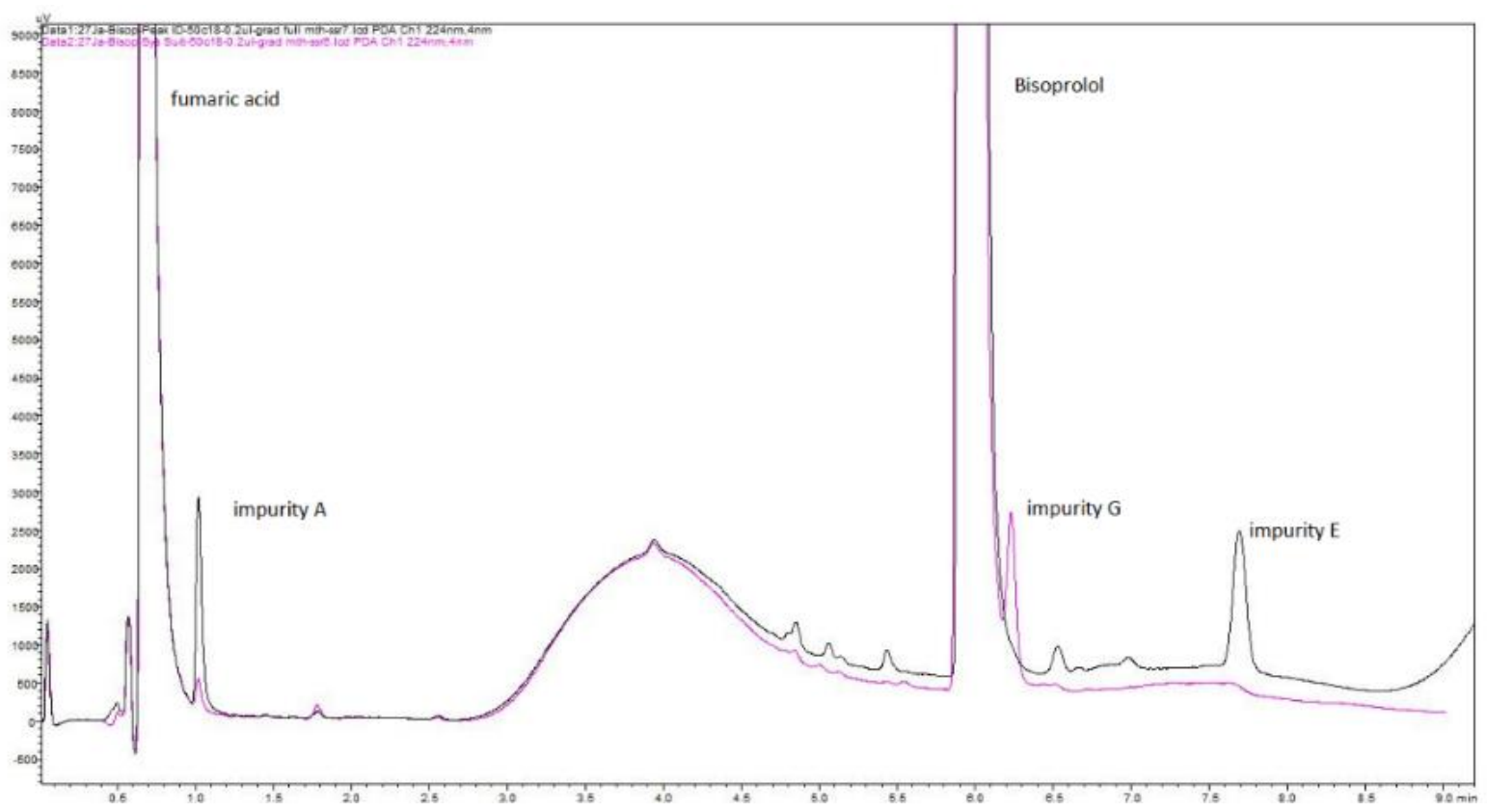

Fig. 4. Chromatograms of the solution for peak identification and the solution for system suitability obtained using Acquity UPLC BEH C18 $50 \times 2.1 \mathrm{~mm}, 1.7 \mu \mathrm{m}$, and gradient elution with acetonitrile and $0.2 \%(\mathrm{v} / \mathrm{v})$ perchloric acid; $0.23 \mathrm{ml} / \mathrm{min}, 20^{\circ} \mathrm{C}(\mathrm{Table} 2)$ 
During the experimental work it appeared that this column can be used in chromatographs with the smallest dwell volume since we have experienced a lack of resolution and delay in peaks elution when changing the HPLC system (to an older one) due to differences in the holdup/dwell volume between systems. Another drawback for using this column in routine analysis is the small optimal injection volume, usually less than $1 \mu \mathrm{l}$ (we used $0.2 \mu \mathrm{l}$ ), that can affect the precision and accuracy between multiple injections with such small injection volumes

Xterra MS C18 $100 \times 4.6 \mathrm{~mm}, 3.5 \mu \mathrm{m}$ was another type of stationary phase tested that is resistant over a wide $\mathrm{pH}$ range and was used with a mobile phase consisting of $0.2 \%(\mathrm{v} / \mathrm{v})$ perchloric acid and acetonitrile with gradient elution. The obtained results showed a good resolution between all tested analytes (Fig. 5).

The experiments presented above have shown many approaches that can be used to ensure satisfactory results considering system suitability parameters. More precisely, the last four experiments can be considered successful when taking into account the obtained results for the resolution between the critical pairs (1 - impurity A and fumaric acid, 2 - bisoprolol and impurity G) and, at the same time, the tailing factor for the peak of impurity E. An overview of the obtained results is presented in Table 3. These results suggest that these four columns and the optimized mobile phase gradients are suitable for their intended use. They comply in terms of having a satisfactory resolution, a well-resolved peak from impurity $\mathrm{E}$, and, at the same time, a reasonable analysis time.

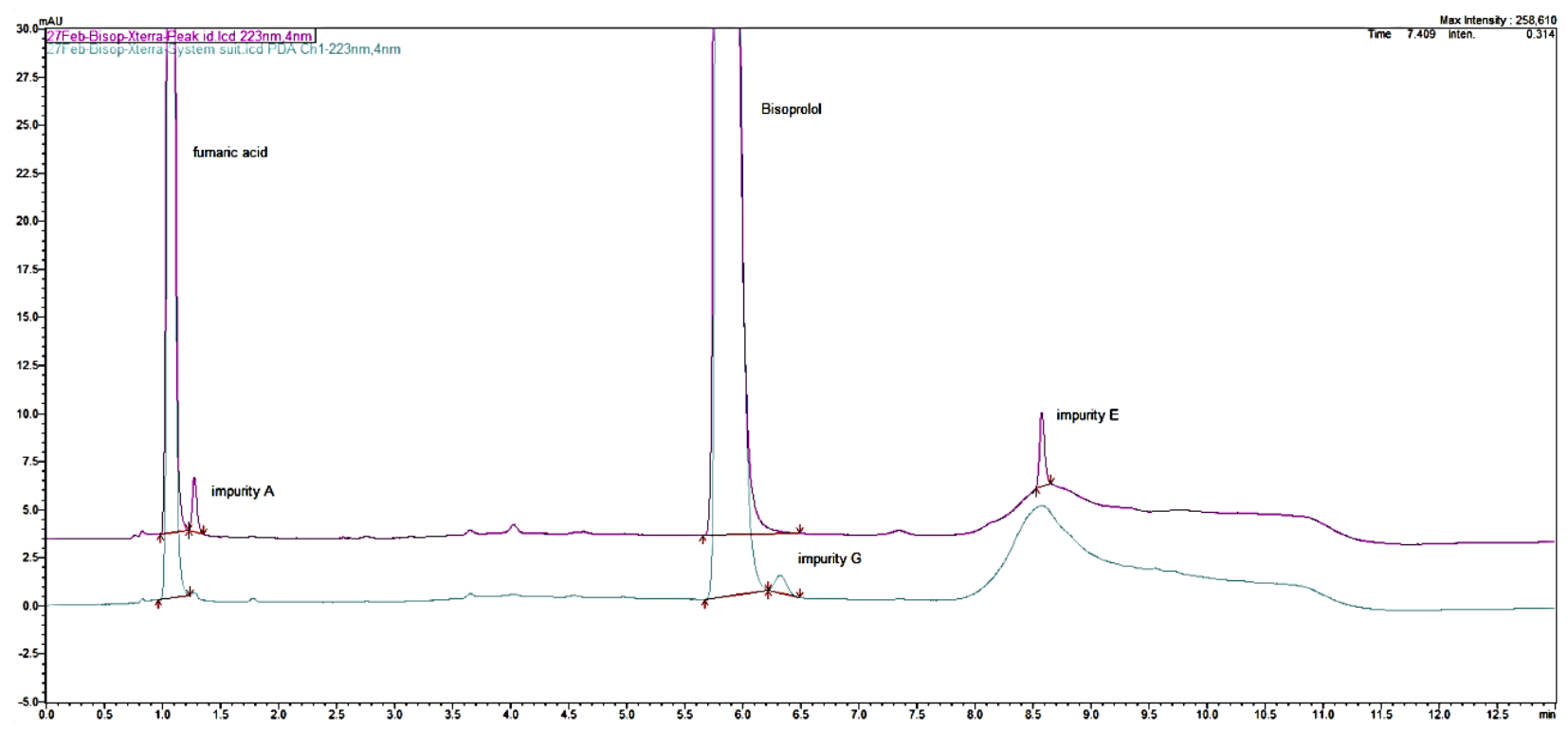

Fig. 5. Chromatograms of the solution for peak identification and the solution for system suitability obtained using Xterra MS C18 $100 \times 4.6 \mathrm{~mm}, 3.5 \mu \mathrm{m}$, and gradient elution with acetonitrile and $0.2 \%(\mathrm{v} / \mathrm{v})$ perchloric acid; $0.23 \mathrm{ml} / \mathrm{min}, 20^{\circ} \mathrm{C}($ Table 2$)$

Table 3

Summary of results obtained for resolution, tailing factor, injection volume, and total analysis time

\begin{tabular}{|c|c|c|c|c|c|}
\hline Experimental conditions & $\begin{array}{c}\text { Resolution } \\
1 *\end{array}$ & $\begin{array}{c}\text { Resolution } \\
2 * *\end{array}$ & $\begin{array}{c}\text { Tailing } \\
\text { factor*** }\end{array}$ & $\begin{array}{c}\text { Injection } \\
\text { volume }\end{array}$ & $\begin{array}{c}\text { Analysi } \\
\text { time }\end{array}$ \\
\hline $\begin{array}{l}\text { Hypersil } 3 \text { BDS C18 } 100 \times \mathbf{4 . 0} \mathbf{~ m m}, \mathbf{3} \boldsymbol{\mu m}, \mathbf{5} \boldsymbol{\mu m} \text {; Gradi- } \\
\text { ent elution, } 0.2 \%(\mathrm{w} / \mathrm{v}) \text { potassium hexafluorophosphate }\end{array}$ & 4.3 & 2.3 & 1.03 & $4 \mu \mathrm{l}$ & $21 \mathrm{~min}$. \\
\hline $\begin{array}{l}\text { Zorbax SB C18 } 150 \times \mathbf{4 . 6} \mathbf{~ m m}, 3.5 \mu \mathrm{m} \text {; } \\
\text { Gradient elution, } 0.2 \%(\mathrm{v} / \mathrm{v}) \text { perchloric acid }\end{array}$ & 2.3 & 2.4 & 1.04 & $4 \mu \mathrm{l}$ & $18 \mathrm{~min}$. \\
\hline $\begin{array}{l}\text { Acquity UPLC BEH C18 50 × } \mathbf{2 . 1} \mathbf{~ m m , ~} \mathbf{1 . 7} \boldsymbol{\mu m} \text {; } \\
\text { Gradient elution, } 0.2 \%(\mathrm{v} / \mathrm{v}) \text { perchloric acid }\end{array}$ & 5.6 & 2.4 & 1.06 & $0.2 \mu \mathrm{l}$ & $12 \mathrm{~min}$. \\
\hline $\begin{array}{l}\text { Xterra MS C18 } 100 \times \mathbf{4 . 6} \mathbf{~ m m}, 3.5 \mu \mathbf{m} \\
\text { Gradient elution, } 0.2 \%(\mathrm{v} / \mathrm{v}) \text { perchloric acid }\end{array}$ & 2.6 & 2.4 & 1.17 & $1 \mu \mathrm{l}$ & 13 min. \\
\hline
\end{tabular}

* Resolution between fumaric acid and impurity A

** Resolution between bisoprolol and impurity $\mathrm{G}$

*** Tailing factor of the peak from impurity $\mathrm{E}$ 
In order to choose the best one, besides the advantages, the drawbacks of all presented systems should be kept in mind. Hypersil 3 BDS C18 $100 \times$ $4.0 \mathrm{~mm}, 3 \mu \mathrm{m}$, is characterized with the longest analysis time. Zorbax SB C18 $150 \times 4.6 \mathrm{~mm}, 3.5$ $\mu \mathrm{m}$, demonstrated excellent results, but the analysis time can still be considered a drawback. Acquity UPLC BEH C18 $50 \times 2.1 \mathrm{~mm}, 1.7 \mu \mathrm{m}$, resulted in the shortest analysis time, the best resolution and tailing factor, and the least mobile phase consumption. However, its drawbacks still need to be considered, such as great column backpressure, differences in the holdup volume between different instruments, and, ultimately, the small injection volume that results in a higher relative standard deviation, RSD between multiple injections. The great column backpressure after repetitive use in everyday laboratory practice will contribute to shortening the column lifetime and is not practical for a great number of analyses.

Xterra MS C18 $100 \times 4.6 \mathrm{~mm}, 3.5 \mu \mathrm{m}$, was finally selected as the best choice in terms of the obtained system suitability parameters, analysis time, column backpressure, and versatility of the mobile phase preparation. Further validation of the analytical method was performed with this column, and the validation results are presented below.

\subsection{Validation of the analytical procedure for} determination of related substances of bisoprolol fumarate in bisoprolol film-coated tablets

The HPLC method is validated according to the propositions recommended in ICH guideline Q2 (R1) [17]. Parameters included in the validation were: linearity, accuracy, system repeatability, method repeatability, and selectivity/specificity.

\subsubsection{Linearity}

Linearity of the method was established in the range from $0.40 \mathrm{mg} / \mathrm{ml}-3.00 \mu \mathrm{g} / \mathrm{ml}$. Response factors were calculated for each concentration level as well as the relative standard deviation of response factors and coefficient of determination $\left(\mathrm{R}^{2}\right)$. The results are acceptable if the obtained values for RSD of the response factors are less than or equal to $10 \%$ and $\mathrm{R}^{2}$ is close to 1.000 .

Linearity was shown to be good in all tested concentration levels. The obtained equation that gives the correlation between peak area and concentration is $y=1336.5 x+55.522$, and the obtained value for $\mathrm{R}^{2}$ is 0.9994 , which confirms the good linear correlation.

\subsubsection{Accuracy}

The accuracy of the method was tested by studying the analytical recovery performed at three concentration levels by spiking the placebo with a known concentration of bisoprolol corresponding to concentrations of $1 \mu \mathrm{g} / \mathrm{ml}, 2 \mu \mathrm{g} / \mathrm{ml}$, and $3 \mu \mathrm{g} / \mathrm{ml}$. The obtained results fit within the acceptance range of 90-110\% (Table 4), which confirm that the recovery of the analytical method is satisfied in all cases.

Table 4

Analytical recovery of bisoprolol

\begin{tabular}{ccc}
\hline \hline $\begin{array}{c}\text { Spiked } \\
\begin{array}{c}\text { concentration } \\
(\mu \mathrm{g} / \mathrm{ml})\end{array}\end{array}$ & $\begin{array}{c}\text { Obtained } \\
\text { concentration } \\
(\mu \mathrm{g} / \mathrm{ml})\end{array}$ & $\begin{array}{c}\text { Recovery } \\
(\%)\end{array}$ \\
\hline 1.010 & 0.955 & 94.47 \\
2.021 & 1.927 & 95.38 \\
3.031 & 2.796 & 92.24 \\
\hline & average & 94.03 \\
\cline { 2 - 3 } & rsd $(\%)$ & 1.63 \\
\hline
\end{tabular}

\subsubsection{Specificity/selectivity}

Specificity and selectivity were established by injecting the system suitability solution, peak identification solution, placebo solution, standard solution, and test solution as well as by solutions obtained from the forced degradation studies. By injecting the diluent, placebo solution, test solution, and standard solution, it was confirmed that excipients from the placebo matrix do not interfere with the peak of bisoprolol and the peaks from related substances.

In the chromatogram of the system suitability solution (Fig. 5), the peaks due to fumaric acid, bisoprolol, and bisoprolol impurity $\mathrm{G}$ were noticed (mentioned as they appeared in the chromatogram). The resolution between the peaks of bisoprolol and bisoprolol impuirty $\mathrm{G}$ was about 2.4. On the chromatogram of the peak identification solution, peaks due to the presence of fumaric acid, bisoprolol impuirty A, bisoprolol, and bisoprolol impurity E were detected (mentioned as they appeared in the chromatogram), with good resolution between fumaric acid and bisoprolol impurity A (about 2.6), and bisoprolol impurity $\mathrm{E}$ was eluted as a well designated and sharp peak with a tailing factor of 1.17 .

To further assess the power of the analytical method to resolve related substances that could eventually be present and arise during the shelf-life period of the finished product, degradation studies were performed. The results obtained during the forced degradation studies confirmed a good resolu- 
tion between bisoprolol and the formed degradation products, and at the same time, confirmed a good mass balance and satisfactory values for the peak purity index $[18,19,20]$ that are shown in Table 5.

Table 5

Mass balance calculation presented as a tabulated overview

\begin{tabular}{lcccccc}
\hline \hline Conditions & Normal & Acid & Alkaline & Oxidative & Temperature & Light \\
\hline $\begin{array}{l}\% \text { content of active } \\
\text { principle }\end{array}$ & $95.06 \%$ & $91.43 \%$ & $84.51 \%$ & $75.08 \%$ & $88.55 \%$ & $87.75 \%$ \\
$\begin{array}{l}\% \text { degradation products } \\
\begin{array}{l}\text { total (sum of \% content } \\
\text { of active principle and } \\
\% \text { degradation products) }\end{array}\end{array}$ & $0.65 \%$ & $5.00 \%$ & $11.94 \%$ & $19.62 \%$ & $5.51 \%$ & $7.60 \%$ \\
\hline Peak purity index* & 87 & $96.43 \%$ & $96.45 \%$ & $94.70 \%$ & $94.06 \%$ & $95.35 \%$ \\
\hline \hline
\end{tabular}

*Determined by LabSolutions software 5.97. Values greater than or equal to zero mean that impurities during the peak elution are not detected.

\subsubsection{Precision}

System repeatability was investigated by calculation of the relative standard deviation of multiple injections of the standard solution (a). The obtained results from multiple injections of the reference solution (a), which are used for quantification, confirmed good reproducibility, with obtained RSD lower than $10 \%$. More precisely, it is $1.34 \%$, which is an acceptable limit and fits within the prescribed criteria.
Method repeatability was determined by injecting five test solutions that are prepared from the same homogenised powdered tablet and calculating the related substances that are eventually present. The obtained results for bisoprolol impurity A were below the limit of quantification, bisoprolol impurity $\mathrm{G}$ and bisoprolol impurity $\mathrm{E}$ were not detected, and the results for any detected and quantified unspecified impurities had a relative standard deviation below $10 \%$ (Table 6).

Table 6

Method repeatability of bisoprolol

\begin{tabular}{cccccccc}
\hline \hline & Impurity A & Impurity G & Impurity E & $\begin{array}{c}\text { Any unspeci- } \\
\text { fied impurity } \\
\text { RRT/0.60 }(\%)\end{array}$ & $\begin{array}{c}\text { Any unspeci- } \\
\text { fied impurity }\end{array}$ & $\begin{array}{c}\text { Any unspeci- } \\
\text { fied impurity }\end{array}$ & $\begin{array}{c}\text { Any unspeci- } \\
\text { fied impurity }\end{array}$ \\
& $(\%)$ & $(\%)$ & $(\%)$ & RRT/1.42 $(\%)$ & RRT/1.52 $(\%)$ \\
\hline Test solution 1 & 0.113 & not detected & 0.065 & 0.074 & 0.051 & 0.049 & 0.111 \\
Test solution 2 & 0.114 & not detected & 0.064 & 0.075 & 0.052 & 0.051 & 0.112 \\
Test solution 3 & 0.115 & not detected & 0.067 & 0.071 & 0.051 & 0.048 & 0.110 \\
Test solution 4 & 0.110 & not detected & 0.063 & 0.076 & 0.056 & 0.053 & 0.109 \\
Test solution 5 & 0.116 & not detected & 0.064 & 0.074 & 0.054 & 0.052 & 0.110 \\
\hline Average & 0.114 & $/$ & 0.065 & 0.074 & 0.053 & 0.051 & 0.110 \\
RSD & 2.03 & $/$ & 2.35 & 2.528 & 4.106 & 4.066 & 1.033 \\
\hline \hline
\end{tabular}

\section{CONCLUSION}

The greatest achievement during the development of the analytical method for determination of related substances of bisoprolol in a finished drug product was obtaining good system suitability parameters, i.e., good resolution between fumaric acid and bisoprolol impurity $\mathrm{A}$ and between bisoprolol and bisoprolol impurity $\mathrm{G}$ as well as elution of the bisoprolol impurity $\mathrm{E}$ in a reasonable amount of time and as a peak with good peak symmetry. In spite of the very similar chemical structures of related substances and bisoprolol, it was possible to achieve it by careful selection of the stationary phase, particle size, column temperature, and mobile phase composition (buffer and its $\mathrm{pH}$, additives such as ion-pair agents or "chaotropic" agents, gradient).

Summarizing all the obtained results, some general conclusions can be made. The chemical structures of the tested analytes have shown that bisoprolol impurity A is very polar and often co- 
elutes with the peak of fumaric acid or, generally, in the front of the chromatogram. Peaks due to the presence of bisoprolol and bisoprolol impurity $\mathrm{G}$ were very hard to resolve because of their very similar structure and required a specific stationary phase and increased interactions with the stationary phase strengthened by adding "chaotropic" ions in the mobile phase and decreasing the column temperature. Elution of bisoprolol impurity $\mathrm{E}$ was another problem because using "chaotropic" ions in the mobile phase for better separation and resolution caused a very strong retention of this compound, and usually, its peak appeared very late and often was split. The solution to this problem was to increase the percentage of the organic part of the mobile phase (acetonitrile) in a stepwise gradient in a short time, which gives a sharp and welldesignated peak of bisoprolol impurity E. An important issue that needs to be emphasized is that using "chaotropic" ions does not alter the stationary phases, which is not the case when adding ionpair reagents in the mobile phase that permanently change its characteristics.

All of the mentioned analytical methods with the favorable chromatographic parameters given in Table 3 are suitable for their intended use, i.e., they are capable of separating well-designated peaks, which are well separated from one another in a run time interval that is shorter than the one that is described in the method for determination of related substances in the monograph for bisoprolol fumarate in the British Pharmacopoeia [4].

\section{REFERENCES}

[1] M. Szalka, J. Kostka, E. Rokaszewski, K. Kaczmarski, Analysis of related substances in bisoprolol fumarate on sub-2- $\mu \mathrm{m}$ adsorbents, Acta Chromatogr. 24(2), 63-183 (2012). DOI: https://doi.org/10.1556/achrom.24.2012.2.2.

[2] D. J. Newman, Natural product-derived drugs based on $\beta$-adrenergic agents and nucleosides, J. Braz. Chem. Soc. 27(8), 1320-1333 (2016).

DOI: https://doi.org/10.5935/0103-5053.20160070.

[3] European Pharmacopoeia, 8th edition, European Directorate for the Quality of Medicines and Healthcare, Council of Europe, Strasbourg, 2014. (Monograph for Bisoprolol fumarate 01/2012:171 published on 1 January 2014).

[4] British Pharmacopoeia, Stationary Office on Behalf of the Medicines and Healthcare Products Regulatory Agency (MHRA), 2018. Monograph for Bisoprolol fumarate in British Pharmacopoeia published on 1 January 2018

[5] T. Rakić, M. Jovanović, A. Tumpa, B. JancićStojanović, M. Medenica, Optimizations of HILIC method for analysis of bisoprolol and its impurities considering uncertainties in peak positions, Arh. Farm. 64, 95-111 (2014). DOI: 10.5937/arhfarm1402095R.
[6] I. Kasagić-Vujanović, B. Jancić Stojanović, D. Ivanović, Monitoring of bisoprolol fumarate stability under different stress conditions, IFMBE Proceedings 62 (2017). DOI: 10.1007/978-981-10-4166-2_64.

[7] I. Mitrović, E. Kikovska-Stojanovska, G. Petrushevski, M. Chachorovska, S. Mehmed-Sejfulah, and S. Ugarkovic, Identification and structural characterization of unidentified impurity in bisoprolol film-coated tablets, Hindawi Advances in Chemistry 2017, 30475717 (2017). DOI: https://doi.org/10.1155/2017/3047517.

[8] C. S. Mahu, F. A. Spac, C. Ciobanu, M. Hancianu, L. Agroroaei, E. Butnaru, Quantitative determination of bisoprolol fumarate by HPLC, I. Method validation, Rev. Chim. 67(3), 414-417 (2016).

[9] S. J. Joshi, P. A. Karbhari., S. I. Bhoir, K. S. Bindu, C. Das, RP-HPLC method for simultaneous estimation of bisoprolol fumarate and hydrochlorothiazide in tablet formulation, J. Pharm Biomed. Anal. 52(3), 362-71 (2010). DOI: 10.1016/j.jpba.2009.10.021.

[10] I. Kasagić-Vujanović, B. Jancić Stojanović, T. Rakić, D. Ivanović, Design of experiments in optimization and validation of a hydrophilic interaction liquid chromatography method for determination of amlodipine besylate and bisoprolol fumarate, J. Liq. Chromatogr. Relat. Technol. 38(8), 919-928 (2015).

[11] I. Kasagić-Vujanović, B. Jancić Stojanović, D. Ivanović, Forced degradation study of amlodipine besylate and bisoprolol fumarate using chromatography with hydrophilic interactions, Arh. Farm. 64(3), 230-24 (2014). DOI: $10.5937 /$ arhfarm1403230K.

[12] ICH Guideline: Stability Testing of New Drug Substance and Product, ICH Q1A(R2), European Medical Agency, CPMP/ICH/2736/99, August 2003.

[13] ICH Guideline: Photostability Testing of New Active Substances and Medicinal Products, ICH Topic Q1B, European Medical Agency, CPMP/ICH/279/95, January 1998.

[14] A. H. Bakheit, A. Raisuddin, A. D. Alshahrania, and A. S. El-Azaba, Chapter Two - Bisoprolol: A comprehensive profile, Profiles of Drug Substances, Excipients, and Related Methodology, 46, 51-89 (2021). DOI: 10.1016/bs.podrm.2020.07.006.

[15] Y. Kazakevic, R. LoBrutto, HPLC for Pharmaceutical Scientists, John Wiley \& Sons, 2007, pp. 139-239.

[16] L. R. Snyder, J. J. Kirkland, J. W. Dolan, Introduction to Modern Liquid Chromatography, Third edition, John Wiley \& Sons, 2010, pp. 404-470.

[17] ICH Guideline: Validation of analytical procedures: Text and Methodology, ICH Q2(R1), European Medical Agency, CPMP/ICH/381/95, November 2005.

[18] W. D. Reynolds, L. K. Facchine, F. J. Mullaney, K. M. Alsante, T. D. Hatajik, and M. G. Motto, Available guidance and best practices for conducting forced degradation studies, Pharm. Technol. 26, 48-56 (2002).

[19] S. Krause, Analytical method development and optimization, BioPharm International, 2008 (2). $\mathrm{https} / / /$ www.biopharminternational.com/view/analyticalmethod-development-and-optimization, accessed July 2021.

[20] Pharmaceutical Technology Editors, Reconciling Mass Balance in Forced Degradation Studies, Pharmaceutical Technology, 29 (10).

https://www.pharmtech.com/view/reconciling-massbalance-forced-degradation-studies, accessed July 2021. 